\title{
Using Plantago major and Plantago lanceolata in environmental pollution research in an urban area of Southern Poland
}

\author{
Iryna Skrynetska ${ }^{1}$ (D) Jagna Karcz ${ }^{2}$ - Gabriela Barczyk ${ }^{1} \cdot$ Marta Kandziora-Ciupa $^{1} \cdot$ Ryszard Ciepał $^{1}$. \\ Aleksandra Nadgórska-Socha ${ }^{1}$
}

Received: 17 December 2018 / Accepted: 21 May 2019 / Published online: 14 June 2019

(C) The Author(s) 2019

\begin{abstract}
The aim of this study was to perform a complex assessment of changes in the elements of an ecosystem that are caused by environmental pollution in industrial and urban biotopes. The study focused on three sites: a park, a road and the site of the metallurgical plant "Pokój" in the city of Ruda Ślaska (Southern Poland), which are each under a different level of anthropogenic load. Soil and plant material samples (Plantago major and Plantago lanceolata leaves) were investigated by performing biochemical, ecophysiological and scanning electron microscopy (SEM) analyses. A significant difference was observed in all of the study samples. The content of $\mathrm{Pb}, \mathrm{Zn}$ and $\mathrm{Cd}$ in the soil samples that had been collected at the site of the metallurgical plant exceeded the permitted limits $\left(\mathrm{Cd}>4 \mathrm{mg} \mathrm{kg}^{-1}, \mathrm{~Pb}>100 \mathrm{mg} \mathrm{kg}^{-1}, \mathrm{Zn}>300 \mathrm{mg} \mathrm{kg}^{-1}\right)$. The content of $\mathrm{Fe}, \mathrm{Mn}, \mathrm{Pb}, \mathrm{Cd}$ and $\mathrm{Zn}$ in the plant material was much higher in unwashed samples than in washed samples. The concentrations of potentially toxic elements (PTEs) were below the permitted level in the leaves of Plantago lanceolata for $\mathrm{Cd}\left(>5 \mathrm{mg} \mathrm{kg}^{-1}\right)$ and in the leaves of Plantago major for $\mathrm{Zn}\left(>100 \mathrm{mg} \mathrm{kg}^{-1}\right)$. The SEM observations revealed a significant decrease in the stomata pore length (SPL) in the Plantago lanceolata leaves that had been collected at the road site compared with the plants from the park site. The elemental content on the leaf surface was also determined using X-ray microanalysis. The total chlorophyll (Chl) content, ascorbic acid (AA), proline, guaiacol peroxidase (GPX) activity, $\mathrm{pH}$, relative water content (RWC) and air pollution tolerance index (APTI) were evaluated. The APTI for the investigated species ranged from 5.6 to 7.4, which demonstrated that the studied plant species are sensitive to air pollutants.
\end{abstract}

Keywords SEM-EDX $\cdot$ APTI $\cdot$ Potentially toxic metals $($ PTMs) $\cdot$ Plantago $\cdot$ Soil pollution

$\begin{array}{ll}\text { Abbreviations } \\ \text { AA } & \text { Ascorbic acid } \\ \text { APTI } & \text { Air pollution tolerance index } \\ \text { Chl } & \text { Total chlorophyll }\end{array}$

Responsible editor: Roberto Terzano

Electronic supplementary material The online version of this article (https://doi.org/10.1007/s11356-019-05535-x) contains supplementary material, which is available to authorized users.

Iryna Skrynetska

i.skrynetska@gmail.com

1 Department of Ecology, Faculty of Biology and Environmental Protection, University of Silesia, Bankowa 9, 40-007 Katowice, Poland

2 Scanning Electron Microscopy Laboratory, Faculty of Biology and Environmental Protection, University of Silesia, Jagiellońska 28, 40-032 Katowice, Poland
GPX
RWC
SEM
SEM-EDX
Guaiacol peroxidase
Relative water content
Scanning electron microscopy
SPL

Scanning electron microscopy with
energy-dispersive X-ray spectroscopy
Stomata pore length

\section{Introduction}

Over the last several decades, the quality of the environment has undergone a significant deterioration, which was primarily due to rapid developments in industry as well as urbanisation. Environmental pollution has become a factor that is responsible for many negative effects on the health of fauna and flora as well as on the ecosystem as a whole because of potentially toxic metals that do not degrade and accumulate in the environment, most of which have long-term toxic effects on living 
organisms (Kardel et al. 2010; Remon et al. 2013; Muszyńska et al. 2018). However, the effects of this interaction on the function and structure of the elements of an urban ecosystem have not yet been adequately quantified and are poorly understood.

In flora, the epidermis is the first site of interaction with atmospheric pollution because pollutants first pass through the stomata of the epidermal tissues. The stomata, which regulate the flow of gases entering into or escaping out of leaves, are an excellent site to study the interaction between plants and their environment because they are the first to be affected by air pollution, which may cause changes in their morphology (Robinson et al. 1998; Kardel et al. 2010; Uka et al. 2017). There are many different biochemical and physiological mechanisms that help plants adapt to pollutants, and their efficiency can be assessed by a number of parameters such as the total chlorophyll (Chl) content, ascorbic acid (AA) content, $\mathrm{pH}$ and relative water content (RWC). All of these indexes make up the so-called air pollution tolerance index (APTI). The value of the APTI defines a plant's tolerance to pollution because these parameters determine a plant's adaptation to the environment and thus predetermine the sensitivity or resistance of a species to pollution (Lakshmi et al. 2008; Prajapati and Tripathi 2008). Additionally, a biochemical assessment of variations in metabolites could be helpful in defining the tolerance of a species. Proline accumulation is regarded as an indicator of heavy metal stress and enzymatic antioxidant components such as GPX may be used as an indicator of environmental stress for an ecosystem (KandzioraCiupa et al. 2017; Nadgórska-Socha et al. 2017).

The aim of this study was to perform a complex assessment of changes in the elements of an ecosystem that are caused by environmental pollution in industrial and urban biotopes. Two ruderal species, Plantago major and Plantago lanceolata, were selected for this study. The Plantago species has been used as a traditional medicinal plant in many parts of the world for centuries (Abd El-Gawad et al. 2015; Gomes de Andrade et al. 2018). Plantago lanceolata and Plantago major are easy to recognize and are very common in urban environments and in the countryside. Previous studies have indicated that the Plantago major and Plantago lanceolata species contain significant levels of trace elements (Tinkov et al. 2016; Nadgórska-Socha et al. 2017; Skrynetska et al. 2018).

The objective of this study was to perform a comparative analysis of selected ecophysiological and biochemical parameters and to determine the metal concentrations in soils and plants in samples that had been collected from three areas with different levels of the anthropogenic load. The data obtained enabled us to observe any differences in the morphology and physiological parameters, to analyse the air pollution tolerance indexes and to assess the potential use of the tested species as a bioindicator in an urban biotope. The tolerance of these plants to metal toxicity was established in order to determine their possible application in soil phytostabilisation and revegetation in industrial areas that have been contaminated with potentially toxic metals (Serbula et al. 2012; Nadgórska-Socha et al. 2013; Romeh et al. 2016). These results may be useful in evaluating the adaptive properties of these plants to harsh environmental conditions as well as their use in ecological risk assessment (Djingova et al. 2004; Przedpełska and Wierzbicka 2007; Słomka et al. 2008).

The following hypotheses were evaluated:

- Metal pollution contributes to changes in the ecophysiological and morphological properties of selected species within polluted sites compared with plants from a noncontaminated area.

- Plantago species may be useful biological indicators for industrialised urban areas.

\section{Material and methods}

\section{Study area}

The investigated areas represented a variety of habitats (green belts, squares, lawns and park) with ruderal and invasive species such as Robinia pseudoacacia, Solidago canadensis and Reynoutria japonica. Ruderal species were represented by Taraxacum officinale, Achillea millefolium, Bellis perennis, Trifolium repens, Poa annua, Medicago lupulina and others.

The study sites were located in the city of Ruda Ślaska (Upper Silesian Industrial District, Southern Poland). For the study, three locations were selected: a road $\left(50^{\circ} 15^{\prime} 17.9^{\prime \prime} \mathrm{N}\right.$, $\left.18^{\circ} 51^{\prime} 17.1^{\prime \prime} \mathrm{E}\right)$, a metallurgical plant $\left(50^{\circ} 17^{\prime} 30.5^{\prime \prime} \mathrm{N}, 18^{\circ} 52^{\prime}\right.$ 25.7" E) and a park (50 $10^{\circ} 28.4^{\prime \prime} \mathrm{N}, 18^{\circ} 50^{\prime} 12.8^{\prime \prime}$ E) (Fig. 1).

The "Strzelnica" Park is a recreational and leisure area and is considered to be a potentially "clean" area. The road is the intersection of the A4 expressway and the provincial road 925, which has intensive road traffic. The metallurgical plant "Pokój," where steel products are produced and distributed, is a site with a high level of environmental pollution.

\section{Soil and plant material collection}

Soil samples were taken from the top layer at $0-10 \mathrm{~cm}$ depth from five locations at each site. The samples were collected during the vegetation season in late June and early July 2016. The soil and plant material samples were collected in five replicates at each site (i.e. a total of 15 soil samples and 15 plant material samples).

Plant materials from herbaceous lawns were selected: greater plantain (Plantago major) and narrow leaf plantain (Plantago lanceolata), which are species of Plantago, family Plantaginaceae. These two ruderal species are common and 


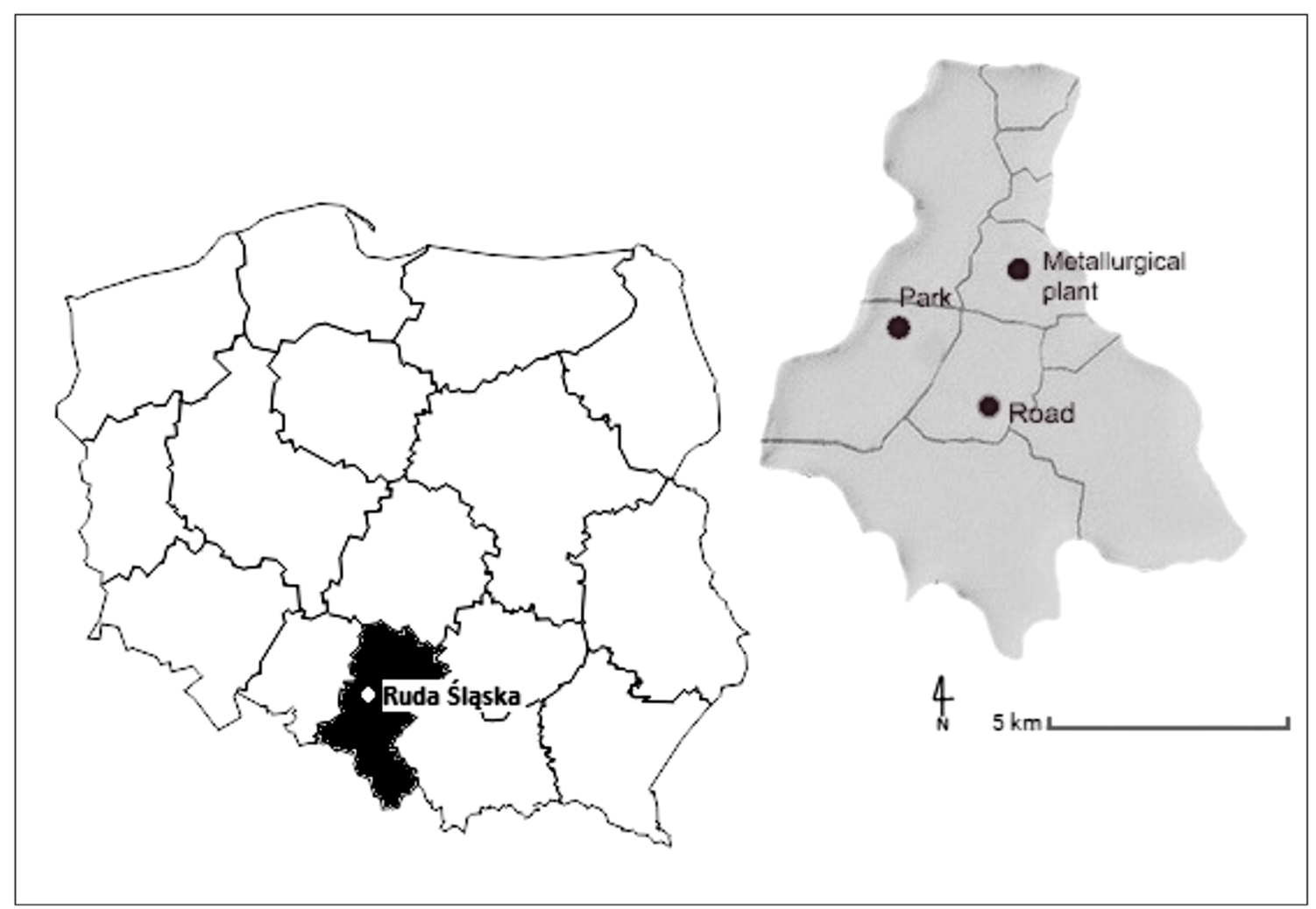

Fig. 1 Location of the study sites in Ruda Ślaska: the road (expressway A4); the site of the metallurgical plant "Pokój" and "Strzelnica" Park

widespread and are also well known as good biological indicators (Kurteva 2009, Nadgórska-Socha et al. 2013, Romeh et al. 2016, Giacomino et al. 2016). The plant material for the biochemical analysis was frozen immediately after collection and kept frozen until the analysis.

\section{Scanning electron microscopy with energy-dispersive X-ray spectroscopy analysis}

SEM was used to investigate the micromorphology of the leaf surfaces and stomata size. Leaves from plants of about the same age were taken randomly. Small pieces of fresh leaves near the central nerve $\left(0.5 \times 1 \mathrm{~cm}^{2}\right)$ were cut from the same area of the leaf lamina, fixed in $3 \%$ glutaraldehyde in a $0.1 \mathrm{M}$ sodium phosphate buffer, washed three times with the same buffer and then dehydrated with ethanol. In the next step, the samples were critical-point dried in a Pelco CPD2 apparatus (Ted Pella Inc., Redding, CA, USA) and then mounted on aluminium stubs with double-sided adhesive carbon tape and at lastly sputter coated in a Pelco SC-6 sputter coater (Ted Pella Inc.) with a $20 \mathrm{~nm}$ layer of gold in order to improve the electrical conductivity properties of the samples. All specimens were imaged using a field emission scanning electron microscope (Hitachi SU8010 FESEM; Hitachi HighTechnologies Corporation, Tokyo, Japan), which was equipped with a secondary electron detector (ESD). The working conditions were $5 \mathrm{kV}$ or $15 \mathrm{kV}$ accelerating voltages, a working distance (WD) ranging from 8 to $25 \mathrm{~mm}$.

Energy-dispersive X-ray microanalysis (EDX) with a detection limit of $0.1 \%$ of weight and beam penetration of 2 $5 \mu \mathrm{m}$ was used to identify the elemental content on the leaf surface using dry plant material that had not been fixed in GA. The parts of the leaves were mounted on aluminium stubs with double-sided adhesive carbon tape and sputter coated with gold. The specimens were examined using a field emission scanning electron microscope (FESEM) and a Thermo Scientific NORAN System 7 energy-dispersive spectrometer (Thermo Fisher Scientific, Madison, WI, USA). Background and element specific peak spectra were analysed with NSS 3 X-ray Microanalysis software (Thermo Fisher Scientific). SEM mode microanalysis was carried out at a $15-\mathrm{kV}$ acceleration and the acquisition time was set to $60 \mathrm{~s}$. Analyses were performed at $\times 500-\times 1100$ magnifications on $1-5$ points of ten randomly selected pieces of the leaves from all of the investigated sites.

\section{Metal content analysis}

The metal content of the soil was determined as pseudo-total $\mathrm{HNO}_{3}$ extractable fraction as was described in detail by Zheljazkov and Nielsen (1996). Additionally, metals were also extracted from the soil samples with $0.01 \mathrm{M} \mathrm{CaCl}_{2}$ (potentially available elements) according to Wójcik et al. (2014). 
The metal content was measured in the filtered extracts using atomic absorption spectroscopy (Thermo Fisher Scientific iCE 3500).

Soil $\mathrm{pH}$ was determined using a standard method (Ostrowska et al. 1991) using a 1:2.5 soil to water ratio. Organic matter content (expressed in \%) was estimated following the method of Ostrowska et al. (1991).

The content of trace elements in the plants was measured using atomic absorption spectrometry (Thermo Fisher Scientific iCE 3500). The plant samples were divided into two groups and analysed as "washed" and "unwashed" samples. The "washed" plants were thoroughly washed with distilled water in an ultrasonic bath (ULTRON, Olsztyn, Poland) for $10 \mathrm{~min}$ at $20{ }^{\circ} \mathrm{C}$ to remove any dust deposits and then rinsed twice with distilled water. The plant samples were dried at $105^{\circ} \mathrm{C}$ and then ground in a stainless steel mill; then, $0.25 \mathrm{~g}$ of the samples was wet digested in concentrated $\mathrm{HNO}_{3}$ at a maximum of $120{ }^{\circ} \mathrm{C}$ and finally diluted to $25 \mathrm{ml}$ with deionised water (Lin et al. 2008).

\section{Biochemical analyses}

Root viability was determined by measuring the GPX activity according to Fang and Kao (2000). Proline accumulation in the leaves was determined using the acid ninhydrin method (Bates et al. 1973). The RWC for the plant samples was determined according to Pathak et al. (2011). The $\mathrm{pH}$ value of the leaves was determined using a $\mathrm{pH}$ meter after homogenising $5 \mathrm{~g}$ f.w. of the leaves in $10 \mathrm{ml}$ deionised water (Nadgórska-Socha et al. 2017). The content of total chlorophyll in the samples was quantitatively determined (Prajapati and Tripathi 2008) in accordance with Arnon (1949). The quantitative determination of ascorbic acid was performed according to Keller and Schwanger (1977) and as described in detail in Nadgórska-Socha et al. (2016).

The calculation of the air pollution tolerance index enables the degree of a plant's tolerance to environmental pollution to be defined. The APTI was calculated according to Prajapati and Tripathi's (2008) formula:

$\mathrm{APTI}=\frac{\mathrm{A} \times(\mathrm{T}+\mathrm{P})+\mathrm{R}}{10}$

where $\mathrm{A}$ is the ascorbic acid content ( $\mathrm{mg} \mathrm{g}^{-1}$ fresh weight); $\mathrm{T}$ is the total leaf chlorophyll content ( $\mathrm{mg} \mathrm{g}^{-1}$ fresh weight); $\mathrm{P}$ is the $\mathrm{pH}$ of leaf extract; $\mathrm{R}$ is the relative water content (\%). According to Singh and Rao (1983), plants with APTI $<10$ are sensitive; $10<\mathrm{APTI}<16$ are medium sensitive and APTI $>17$ are resistant to air pollution.

Extra material about the methodology that was used is included in the supplementary material (Online Resource 1).

\section{Statistical analyses}

All of the statistical calculations were performed using Statistica version 13 (StatSoft Inc., Tulsa, OK, USA). The observations were replicated five times for each parameter. The mean standard error was also calculated. Significant statistical differences were estimated using Tukey's test. The Pearson coefficient of correlation for assessing estimated parameters was also calculated. Analysis of variance (ANOVA) helped to determine the variables that were significantly different among the soil and plant materials.

\section{Results and discussion}

\section{Soil analysis}

Soil pollution, particularly due to potentially toxic metal contamination, has been widely investigated by researchers around the world as one of the major environmental problems that can affect plant productivity, the environment and human health (Ross 1994; Alloway 1997; Kabata-Pendias and Pendias 2001; Kandziora-Ciupa et al. 2016). Previous soil metal accumulation researches that have been conducted in the urban areas of Upper Silesia (Miasteczko Ślaskie, Chorzów, Piekary Śląskie, Sosnowiec, Dąbrowa Górnicza) have also reported excessive concentrations of $\mathrm{Pb}, \mathrm{Cd}$ and $\mathrm{Zn}$ especially in soil samples that had been collected from areas near metallurgical plants (Nadgórska-Socha et al. 2013, 2016; Kandziora-Ciupa et al. 2013; Dziubanek et al. 2015; Skrynetska et al. 2018). Most of these studies were based on the fractions of the extracted elements. According to Zheljazkov et al. (2008), while the pseudo-total or $\mathrm{HNO}_{3}$ extractable soil metal concentrations are important, the phytoavailable forms of specific metals in the soil are the ones to which plant roots are actually exposed. Amoakwah et al. (2013) noted that $\mathrm{CaCl}_{2}$ mobilises both $\mathrm{Cd}$ and $\mathrm{Zn}$ because of the combined effect of complexation by the chloride anion and cation exchange.

Taking into consideration both points, in our study, we elected to use both methods of metal extraction. According to the Regulation by the Minister of Environment (2002), the metal concentrations in the soil pseudo-total fraction, particularly cadmium, lead and zinc, exceeded the permissible concentrations at the site of the metallurgical plant site (4 $\mathrm{mg} \mathrm{kg}^{-1}, 100 \mathrm{mg} \mathrm{kg}^{-1}$ and $300 \mathrm{mg} \mathrm{kg}^{-1}$, respectively). The potentially toxic elements are usually extracted to a greater extent using $\mathrm{HNO}_{3}$ extraction rather than $\mathrm{CaCl}_{2}$ extraction, which was confirmed by our study. In most cases, the potentially bioavailable toxic metal content was below $1 \%$ of the estimated content of the elements in the soil fraction that had been extracted using $\mathrm{HNO}_{3}$. In the $\mathrm{CaCl}_{2}$ extracted concentrations, the highest content of $\mathrm{Mn}, \mathrm{Zn}$ and $\mathrm{Cd}$ was recorded at 
Table 1 Analysis of the soil samples.

\begin{tabular}{|c|c|c|c|c|c|c|c|c|}
\hline Stand & Extraction & $\operatorname{Mn}\left(\mathrm{mg} \mathrm{kg}^{-1}\right)$ & $\mathrm{Fe}\left(\mathrm{mg} \mathrm{kg}^{-1}\right)$ & $\mathrm{Pb}\left(\mathrm{mg} \mathrm{kg}^{-1}\right)$ & $\mathrm{Cd}\left(\mathrm{mg} \mathrm{kg}^{-1}\right)$ & $\mathrm{Zn}\left(\mathrm{mg} \mathrm{kg}^{-1}\right)$ & Organic matter $(\%)$ & $\mathrm{pH}$ \\
\hline Road & $\begin{array}{l}\mathrm{HNO}_{3} \\
\mathrm{CaCl}_{2}\end{array}$ & $\begin{array}{l}236 \pm 68^{\mathrm{a}} \\
0.8 \pm 0.2^{\mathrm{a}}\end{array}$ & $\begin{array}{l}6198 \pm 1124^{\mathrm{a}} \\
0.3 \pm 0.1^{\mathrm{a}}\end{array}$ & $\begin{array}{l}34.7 \pm 2.4^{\mathrm{a}} \\
0.5 \pm 0.1^{\mathrm{a}}\end{array}$ & $\begin{array}{l}0.7 \pm 0.1^{\mathrm{a}} \\
0.1 \pm 0.0^{\mathrm{a}}\end{array}$ & $\begin{array}{l}133 \pm 5^{\mathrm{a}} \\
0.1 \pm 0.0^{\mathrm{a}}\end{array}$ & $6.0 \pm 0.1^{\mathrm{a}}$ & $7.0 \pm 0.3^{b}$ \\
\hline Park & $\begin{array}{l}\mathrm{HNO}_{3} \\
\mathrm{CaCl}_{2}\end{array}$ & $\begin{array}{l}820 \pm 41^{\mathrm{b}} \\
27 \pm 4^{\mathrm{ab}}\end{array}$ & $\begin{array}{l}8765 \pm 342^{\mathrm{bc}} \\
0.4 \pm 0.1^{\mathrm{a}}\end{array}$ & $\begin{array}{l}51.2 \pm 6.5^{\mathrm{a}} \\
0.5 \pm 0.1^{\mathrm{a}}\end{array}$ & $\begin{array}{l}2.1 \pm 0.1^{\mathrm{b}} \\
0.5 \pm 0.0^{\mathrm{b}}\end{array}$ & $\begin{array}{l}237 \pm 17^{\mathrm{a}} \\
15 \pm 1^{\mathrm{b}}\end{array}$ & $8.1 \pm 0.1^{\mathrm{b}}$ & $5.5 \pm 0.1^{\mathrm{a}}$ \\
\hline Metallurgical plant & $\begin{array}{l}\mathrm{HNO}_{3} \\
\mathrm{CaCl}_{2}\end{array}$ & $\begin{array}{l}596 \pm 40^{\mathrm{a}} \\
0.9 \pm 0.1^{\mathrm{a}}\end{array}$ & $\begin{array}{l}42,320 \pm 1678^{\mathrm{c}} \\
0.4 \pm 0.1^{\mathrm{a}}\end{array}$ & $\begin{array}{l}693 \pm 63^{\mathrm{b}} \\
0.6 \pm 0.1^{\mathrm{a}}\end{array}$ & $\begin{array}{l}7.2 \pm 0.6^{\mathrm{c}} \\
0.1 \pm 0.0^{\mathrm{a}}\end{array}$ & $\begin{array}{l}2222 \pm 228^{\mathrm{b}} \\
0.5 \pm 0.1^{\mathrm{a}}\end{array}$ & $13.0 \pm 0.1^{\mathrm{bc}}$ & $7.2 \pm 0.6^{\mathrm{c}}$ \\
\hline
\end{tabular}

Data is expressed as the mean $\pm \mathrm{SD}$. The different letters denote significant differences between specific metal concentrations in the fraction that had been extracted with $\mathrm{HNO}_{3}$ and $\mathrm{CaCl}_{2}$, organic matter content, and $\mathrm{pH}(p<0.05)$

the park, which may be connected with low $\mathrm{pH}$. By contrast, the $\mathrm{CaCl}_{2}$ extracted fraction had a comparable level of lead with an average of $0.5 \mathrm{mg} \mathrm{kg}^{-1}$ and iron content with an average $0.4 \mathrm{mg} \mathrm{kg}^{-1}$ for all of the investigated sites (Table 1). Our results are similar to a study in the nearby Miasteczko Śląskie, Poland (Nadgórska-Socha et al. 2016). According to Meers et al. (2007), the $0.01 \mathrm{M} \mathrm{CaCl}_{2}$ extraction procedure proved to be the most versatile because it provided a good indication of phytoavailability.

The results that were obtained from the investigated locations provide clear information about the impact of pollution on a natural environment that is under pressure from industrialisation and urbanisation. Soils in a city are characterised by a high level of acidity and show a high level of mechanical damage as a result of human activity. Despite this, in our study, the $\mathrm{pH}$ of the surface soils at the road and the site of the metallurgical plant were nearly neutral, thus confirming the efficiency of the revitalisation programmes that began in 2015 (The Local Revitalisation Programme of the City of Ruda Ślaska until 2030 (2015)). The study of the selected sites showed that the average level of organic matter was $9 \%$. The lowest content was found at the road (Table 1).

\section{Analysis of plant material}

\section{SEM observation}

Accumulation of particles on surface of leaves depends on physico-chemical nature of the particulates and the characteristics of the contact surface (Bussotti et al. 1995; Liang et al. 2017). The interaction between plants and the atmosphere occurs mainly via the stomata and therefore can be considered to be an air quality indicator. A study of the stomatal characteristics is an inexpensive and easy way to obtain relevant results (Kardel et al. 2010).

A preliminary examination of the leaves was performed using light microscopy. Plantago major leaves have a blunt apex, 3-9 nerves, are sometimes slightly serrated, a naked or slightly hairy surface and a round shape. The leaves of Plantago lanceolata have a lanceolata or elliptic shape. Its leaf blade is usually full and rarely has a few serrations. In both of the investigated species, the abaxial surface of the leaves is lighter than the adaxial surface. No epicuticular waxes were present on the surfaces of the leaves. Fine deposits with irregular shapes and of different sizes were seen on the surfaces of the leaves in a polluted environment (the area near the road and the site of the metallurgical plant) (Fig. 2b, c, e, and f). At the road, the stomata were mostly closed and blocked by dust (Fig. $2 b$, e). Single trichomes were rarely observed on surfaces of the leaves from all of the investigated sites (Fig. 2b, c, and $\mathrm{f}$ ).

Amphistomatous leaves and stomata occurred on both sides of the leaves in all of the Plantago lanceolata and Plantago major plants that were observed. The study of the micromorphology and anatomy of the Plantago lanceolata leaves using SEM revealed differences in the SPL in the area that has heavy traffic and near the site of the metallurgical plant compared with the park. The highest SPL values were found in the Plantago lanceolata $(24.04 \pm$ $1.26 \mu \mathrm{m}$ ) leaves at the park. Despite the fact that the SPL values in the leaves of Plantago major were much lower at the park $(16.5 \pm 0.75 \mu \mathrm{m})$, the lowest values for Plantago lanceolata $(13.58 \pm 0.95 \mu \mathrm{m})$ and for Plantago major $(14.53 \pm 0.65 \mu \mathrm{m})$ were recorded at the road. At the site of the metallurgical plant, the average SPL was $16.4 \pm$ $0.91 \mu \mathrm{m}$ and $18.23 \pm 0.6 \mu \mathrm{m}$ for Plantago lanceolata and Plantago major, respectively. The leaves of Plantago major had a comparable SPL at all of the investigated sites. A strong positive correlation was observed between the SPL and RWC, total chlorophyll content and APTI $\left(r^{2}=\right.$ $0.7, r^{2}=0.55$ and $r^{2}=0.7$, respectively) and a negative correlation was observed between the SPL and ascorbic acid and proline content $\left(r^{2}=-0.58\right.$ and $r^{2}=-0.81$, respectively). No correlation was observed between the SPL and metal content in either the washed or unwashed plant samples.

Wagoner (1975) reported no differences in the size of the stomata between polluted and unpolluted sites. Alves et al. (2008) described that an increase in stomatal density together with a decrease in stomatal size leads to an optimal adjustment for the control of gas exchange and the 

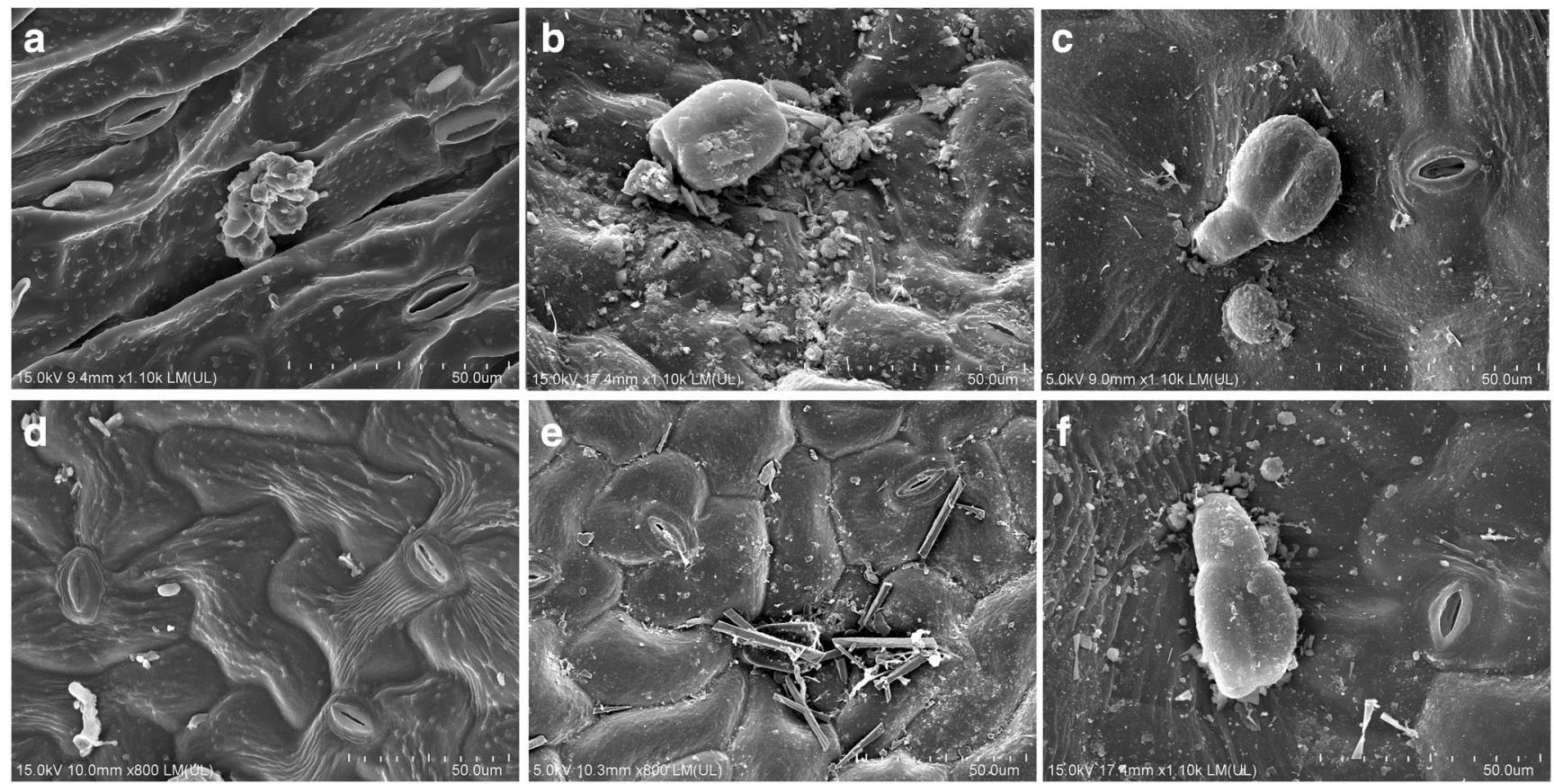

Fig. 2 Representative SEM images of the adaxial surfaces of the leaves. a Plantago lanceolata at the park. b Plantago lanceolata at the road. c Plantago lanceolata at the site of the metallurgical plant. d Plantago

entrance of pollutants through the stomata. Moreover, Kardel et al. (2010) noticed a decrease in both the adaxial and abaxial stomata sizes in the leaves of Plantago lanceolata that acts as a mechanism for adapting to pollution stress in unsuitable habitats. The formation of smaller stomata in the leaf epidermis of trees was also recorded in Lublin, Poland (Chwil et al. 2015).

\section{X-ray microanalysis}

Quantitative EDX analysis only provided information on the distribution of the elements and was not sensitive in depicting low concentrations of the elements (below the detection limit $(>0.1 \%$ weight)). We also analysed the elemental composition of the particles on the adaxial leaf surfaces. X-ray microanalysis revealed the presence of $\mathrm{Si}, \mathrm{Fe}, \mathrm{S}, \mathrm{Na}, \mathrm{Ca}, \mathrm{Mg}, \mathrm{Cl}, \mathrm{O}$, $\mathrm{K}$ and $\mathrm{Al}$ over the entire leaf surface sections that were examined. The results are presented as the averages of the spectra that were obtained at the study sites (Fig. 3). The gold ( $\mathrm{Au}$ ) signals can be considered to have originated from the sputter coating.

The element content on the adaxial leaf surfaces from the park was mainly represented by $\mathrm{O}, \mathrm{C}, \mathrm{K}, \mathrm{Cl}, \mathrm{Ca}$ and $\mathrm{Mg}$ (Fig. $3 \mathrm{a}, \mathrm{b}$ ), while at the road and the site of the metallurgical plant, additional elements were present ( $\mathrm{Na}, \mathrm{Al}, \mathrm{Si}$ and $\mathrm{Fe}$ ) (Fig. 3c$\mathrm{f}$. The highest peaks of $\mathrm{Si}$ and $\mathrm{Al}$ were recorded at the road, and a higher $\mathrm{Fe}$ content was recorded at the site of the metallurgical plant, along with the presence of $\mathrm{Mn}$ and fungal spores (not shown). major at the park. e Plantago major at the road. f Plantago major at the site of the metallurgical plant

Almost the same elemental content was recorded on the surfaces in Bignoniaceae family leaves that had been collected from different areas of the Pune District, India (Kedar et al. 2018). In research conducted by $\overline{\text { Weerakkody et al. (2018) }}$ near a busy road, the amounts of $\mathrm{C}$ and $\mathrm{O}$, in addition to $\mathrm{Fe}$ and $\mathrm{Cl}$, were considerably larger compared with the other elements in $\mathrm{PM}_{10}$, and $\mathrm{Ca}, \mathrm{K}, \mathrm{Si}, \mathrm{Mg}$ and $\mathrm{S}$ were present in particles of various sizes distributed on the leaves of all investigated species. According to Weerakkody et al. (2018), a high content of $\mathrm{C}$ and $\mathrm{O}$ can also indicate the presence of carcinogenic polycyclic aromatic hydrocarbons, primarily from fuel exhausts and tyre wear. Trace amounts of $\mathrm{Ca}, \mathrm{Ba}, \mathrm{Mn}, \mathrm{K}, \mathrm{Mg}$ and $\mathrm{Zn}$ can also be present in vehicle exhausts bound to organic components (Lin et al. 2005; Sharma et al. 2013). In addition to the dust that originates from road traffic, $\mathrm{PM}_{10}$ containing $\mathrm{Al}, \mathrm{Ca}, \mathrm{Na}, \mathrm{Si}, \mathrm{Cl}, \mathrm{F}$ and $\mathrm{N}$ can originate from soil dust (Maher et al. 2013; Weerakkody et al. 2018).

\section{Analysis of the metal content in the plant material}

According to other researchers, the foliar metal uptake is mainly due to the soil-root pathway in urban and industrial environments (Schreck et al. 2012; Dao et al. 2014; Kandziora-Ciupa et al. 2017). The concentrations of the elements $(\mathrm{Fe}, \mathrm{Mn}, \mathrm{Pb}, \mathrm{Cd}, \mathrm{Zn})$ were investigated in both washed and unwashed leaves of Plantago major and Plantago lanceolata. Higher metal concentrations were found in the unwashed samples, which was predictable as the dust on the surfaces of leaves can also contain metals (Maher et al. 2013; 
Fig. 3 Selected SEM-EDX images of Plantago leaf samples with the chemical compositions of the most frequently identified elements on the adaxial surfaces. a, b The park. c, $\mathbf{d}$ The road. e, $\mathbf{f}$ The site of the metallurgical plant a
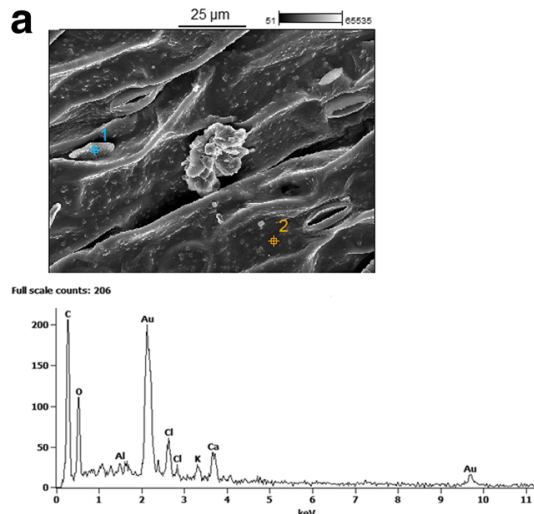

C
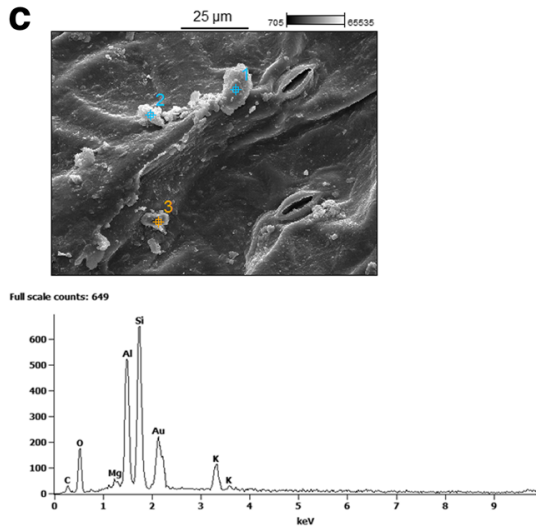

e
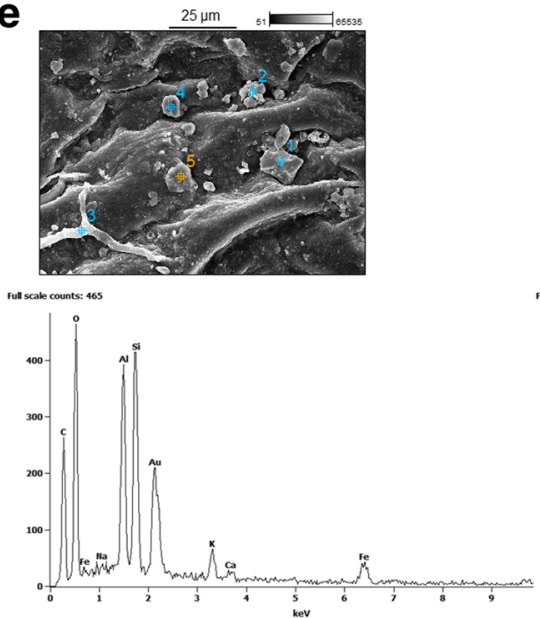

b

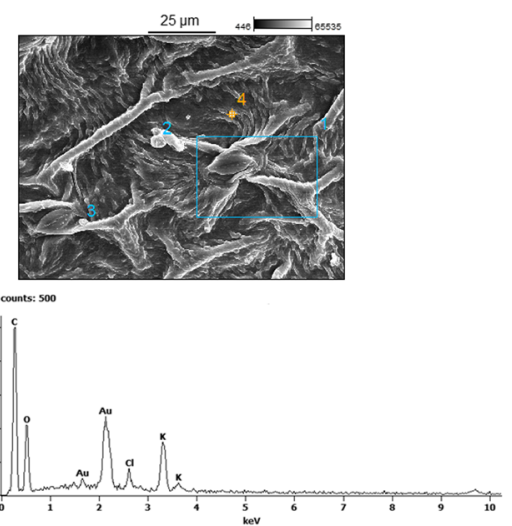

\section{d}
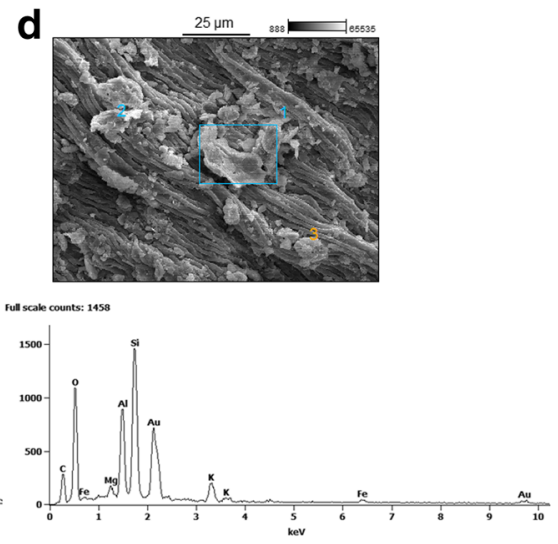

$\mathbf{f}$
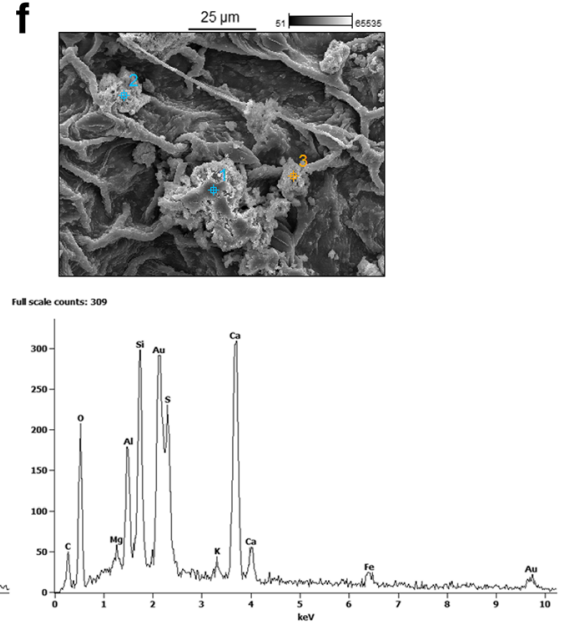

Weerakkody et al. 2018). In the washed plant material, the highest accumulation of $\mathrm{Mn}, \mathrm{Fe}$ and $\mathrm{Pb}$ was recorded in the leaves of Plantago lanceolata at the site of the metallurgical plant (Table 2).

In the study area, the highest concentrations of $\mathrm{Zn}$ were found in the unwashed samples at the site of the metallurgical plant site for both of the species that were studied. The average was $61 \mathrm{mg} \mathrm{kg}^{-1}$ for Plantago major and $43 \mathrm{mg} \mathrm{kg}^{-1}$ for Plantago lanceolata in the washed samples, and the average was $106 \mathrm{mg} \mathrm{kg}^{-1}$ for Plantago major and $88 \mathrm{mg} \mathrm{kg}^{-1}$ for Plantago lanceolata in the unwashed samples (Table 2).
The iron content in the study area ranged from 51 to $391 \mathrm{mg} \mathrm{kg}^{-1}$ for the washed samples and from 308 to $2830 \mathrm{mg} \mathrm{kg}^{-1}$ for the unwashed samples. The highest concentrations were observed in both study species at the site of the metallurgical plant. The $\mathrm{Pb}$ concentration was a few times greater in the unwashed than in the washed plants. The highest manganese concentration was recorded in the leaves of Plantago major in the unwashed samples $\left(792 \mathrm{mg} \mathrm{kg}^{-1}\right)$ at the site of the metallurgical plant, which is eight times higher than the concentration in the washed samples (Table 2).

Potentially toxic concentrations of $\mathrm{Cd}\left(>5 \mathrm{mg} \mathrm{kg}^{-1}\right)$ were found in all of the samples of Plantago lanceolata leaves from 
Table 2 Analysis of the metal content in Plantago lanceolata (Pl) and Plantago major (Pm)

\begin{tabular}{|c|c|c|c|c|c|c|c|c|c|c|c|}
\hline & & \multicolumn{2}{|c|}{$\mathrm{Mn}\left(\mathrm{mg} \mathrm{kg}^{-1}\right)$} & \multicolumn{2}{|c|}{$\mathrm{Fe}\left(\mathrm{mg} \mathrm{kg}^{-1}\right)$} & \multicolumn{2}{|l|}{$\mathrm{Pb}\left(\mathrm{mg} \mathrm{kg}^{-1}\right)$} & \multicolumn{2}{|c|}{$\mathrm{Cd}\left(\mathrm{mg} \mathrm{kg}^{-1}\right)$} & \multicolumn{2}{|l|}{$\mathrm{Zn}\left(\mathrm{mg} \mathrm{kg}^{-1}\right)$} \\
\hline & & Washed & Unwashed & Washed & Unwashed & Washed & Unwashed & Washed & Unwashed & Washed & Unwashed \\
\hline \multirow[t]{2}{*}{ Road } & $\mathrm{Pl}$ & $14 \pm 1^{\mathrm{a}}$ & $41 \pm 4^{\mathrm{a}}$ & $76 \pm 3^{\mathrm{a}}$ & $408 \pm 24^{\mathrm{a}}$ & $0.4 \pm 0.1^{\mathrm{a}}$ & $4.0 \pm 0.2^{\mathrm{a}}$ & $7.9 \pm 0.2^{\mathrm{de}}$ & $10.0 \pm 0.3^{b c}$ & $16.1 \pm 3.2^{\mathrm{a}}$ & $27.6 \pm 2.9^{\mathrm{a}}$ \\
\hline & $\mathrm{Pm}$ & $20 \pm 1^{\mathrm{a}}$ & $25 \pm 3^{\mathrm{a}}$ & $90 \pm 3^{\mathrm{a}}$ & $308 \pm 34^{\mathrm{a}}$ & $0.9 \pm 0.1^{\mathrm{d}}$ & $4.7 \pm 0.2^{\mathrm{a}}$ & $0.1 \pm 0.0^{\mathrm{a}}$ & $0.5 \pm 0.0^{\mathrm{a}}$ & $25.3 \pm 2.1^{\mathrm{ab}}$ & $33 \pm 3^{\mathrm{a}}$ \\
\hline \multirow[t]{2}{*}{ Park } & $\mathrm{Pl}$ & $18 \pm 2^{\mathrm{a}}$ & $46 \pm 2^{\mathrm{a}}$ & $51 \pm 4^{\mathrm{a}}$ & $443 \pm 9^{\mathrm{a}}$ & $0.4 \pm 0.0^{\mathrm{abc}}$ & $5.1 \pm 0.1^{\mathrm{a}}$ & $8.4 \pm 0.1^{\mathrm{f}}$ & $10.4 \pm 0.3^{\mathrm{bc}}$ & $38.6 \pm 3.8^{\mathrm{b}}$ & $70.8 \pm 8.9^{\mathrm{a}}$ \\
\hline & $\mathrm{Pm}$ & $61 \pm 3^{\mathrm{b}}$ & $84 \pm 4^{\mathrm{a}}$ & $92 \pm 8^{\mathrm{a}}$ & $410 \pm 35^{\mathrm{a}}$ & $1.1 \pm 0.0^{\mathrm{c}}$ & $3.3 \pm 0.1^{\mathrm{a}}$ & $1.6 \pm 0.1^{\mathrm{c}}$ & $12.2 \pm 0.5^{\mathrm{c}}$ & $130 \pm 6^{\mathrm{d}}$ & $138 \pm 9^{\mathrm{a}}$ \\
\hline \multirow{2}{*}{$\begin{array}{l}\text { Metallurgical } \\
\text { plant }\end{array}$} & $\mathrm{Pl}$ & $133 \pm 6^{\mathrm{d}}$ & $307 \pm 31^{b}$ & $391 \pm 46^{\mathrm{b}}$ & $1667 \pm 110^{\mathrm{b}}$ & $9.0 \pm 0.3^{\mathrm{e}}$ & $26 \pm 3^{\mathrm{b}}$ & $8.0 \pm 0.1^{\mathrm{e}}$ & $9.9 \pm 0.4^{\mathrm{bc}}$ & $73.8 \pm 5.2^{\mathrm{c}}$ & $165 \pm 2^{b}$ \\
\hline & $\mathrm{Pm}$ & $93 \pm 8^{\mathrm{c}}$ & $792 \pm 4^{c}$ & $314 \pm 17^{\mathrm{b}}$ & $2830 \pm 139^{c}$ & $0.6 \pm 0.0^{\mathrm{b}}$ & $27 \pm 1^{\mathrm{b}}$ & $0.8 \pm 0.1^{\mathrm{b}}$ & $10.2 \pm 0.6^{\mathrm{c}}$ & $27.8 \pm 1.3^{\mathrm{ab}}$ & $148 \pm 7^{\mathrm{a}}$ \\
\hline
\end{tabular}

Data are expressed as the mean $\pm \mathrm{SD}$. The different letters denote significant differences between the metal concentrations in the various plants in the washed and unwashed samples $(p<0.05)$.

the entire study area, according to the limits reported by Kabata-Pendias and Pendias (2001). Moreover, the permissible $\mathrm{Cd}$ content was exceeded in almost all of the unwashed samples, except for the leaves of Plantago major at the road (Table 2). Cd accumulation in edible plants has been found at significantly lower concentrations, i.e. 0.8 to $0.1 \mathrm{mg} \mathrm{kg}^{-1}$ (Dziubanek et al. 2015) compared with our results. A field study conducted by Nadgórska-Socha et al. (2017) also reported a lower metal content in Taraxacum officinale, Plantago lanceolata, Betula pendula and Robinia pseudoacacia leaves. Stafford et al. (2016) noted that the $\mathrm{Cd}$ accumulation in Plantago lanceolata ranged from 0.44 to $0.89 \mathrm{mg} \mathrm{kg}^{-1}$. In our study, the highest concentration of $\mathrm{Zn}$ in the washed samples, which exceeded the permissible concentration $100 \mathrm{mg} \mathrm{kg}^{-1}$ (Kabata-Pendias and Pendias 2001), was found in the leaves of Plantago major at the park site. By contrast, the study conducted by Kurteva (2009) recorded a higher $\mathrm{Zn}$ accumulation in the leaves of Plantago lanceolata. Our investigation of the accumulation of potentially toxic metals found much higher metal concentrations in the soil and leaves of Plantago major compared with the study in Cluj-Napoca, Romania, of Levei et al. (2018).

After averaging the data that was obtained in the measurements, the concentrations of the elements in the washed samples can be ranked in the following descending order for Plantago lanceolata: $\mathrm{Fe}>\mathrm{Mn}>\mathrm{Zn}>\mathrm{Cd}>\mathrm{Pb}$ and for Plantago major: $\mathrm{Fe}>\mathrm{Zn}>\mathrm{Mn}>\mathrm{Pb}>\mathrm{Cd}$ as was also recorded for Plantago major in Sosnowiec (Skrynetska et al. 2018). The order of the concentrations in the unwashed samples for both Plantago species was the same: $\mathrm{Fe}>\mathrm{Mn}>\mathrm{Zn}>\mathrm{Pb}>\mathrm{Cd}$. This fact supports the crucial point that the plant samples that are used in biomonitoring studies must be washed.

\section{Analysis of the biochemical parameters}

To estimate the state of the environment, in addition to the above-mentioned results, the total chlorophyll, proline, ascorbic acid, relative water content and leaf $\mathrm{pH}$ were determined. The GPX activity was also analysed (Table 3 ).

Proline accumulation is considered to be a common physiological response of many plants to environmental stress factors (Verbruggen and Hermans 2008; Tantrey and Agnihotri 2010). Moreover, researchers have found a significant amount of proline in the reproductive parts of different plant species, which raises the possibility that the accumulation of this amino acid may also occur in non-stressed physiological conditions (Mattioli et al. 2009). Numerous studies have also noted a higher content of proline in samples from contaminated areas compared with potentially clean sites (Tantrey and Agnihotri 2010; Kumar et al. 2010; Kandziora-Ciupa et al. 2016; Kandziora-Ciupa et al. 2017). In our investigation, the highest proline content was recorded at the road site for both of the study species (Table 3). The average proline contents for the Plantago major and Plantago lanceolata leaves were $7.8 \mu \mathrm{mol} \mathrm{g}^{-1}$ and $8.5 \mu \mathrm{mol} \mathrm{g}^{-1}$ f.w., respectively (Table 3). An increase in the proline level during environmental contamination was also found in Philadelphus coronarius leaves by Kafel et al. (2010) and confirmed in Taraxacum officinale, Plantago lanceolata, Betula pendula and Robinia pseudoacacia leaves because of urban environmental traffic contamination by Nadgórska-Socha et al. (2017). In a field study near the site of a smelter, a higher proline content was also recorded in the leaves of Vaccinium murtillus (KandzioraCiupa et al. 2017).

GPX activity is significant for plant growth and development. The activity of antioxidant enzymes changes under biotic and abiotic stress conditions and can be used as a potential indicator of metal toxicity and other stress factors (Verma and Dubey 2003; Doğanlar and Atmaca 2011; Kandziora-Ciupa et al. 2017). According to the obtained results, a higher level of GPX activity was recorded in the leaves of Plantago major at the site of the metallurgical plant (1254 tetra-guaiacol $\mathrm{g}^{-1}$ f.w.), while the lowest was recorded in the Plantago lanceolata leaves (348 tetra-guaiacol $\mathrm{g}^{-1}$ f.w.) at the road (Table 3). In our study, a lower GPX activity was recorded 
Table 3 Analysis of the biochemical parameters of Plantago lanceolata $(\mathrm{Pl})$ and Plantago major $(\mathrm{Pm})$

\begin{tabular}{|c|c|c|c|c|c|c|c|c|}
\hline & & $\operatorname{GPX}\left(\mu \mathrm{g} \mathrm{g}{ }^{-1}\right.$ f.w. $)$ & Proline ( $\mu \mathrm{mol} \mathrm{g}^{-1}$ f.w.) & RWC (\%) & Chl (mg g ${ }^{-1}$ f.w.) & $\mathrm{pH}$ & AA ( $\mathrm{mg} \mathrm{g}^{-1}$ f.w.) & APTI \\
\hline \multirow[t]{2}{*}{ Road } & Pl & $348 \pm 4^{\mathrm{a}}$ & $9.8 \pm 0.5^{\mathrm{b}}$ & $60 \pm 3^{\mathrm{a}}$ & $0.13 \pm 0.01^{\mathrm{ab}}$ & $4.5 \pm 0.1^{\mathrm{a}}$ & $0.48 \pm 0.02^{\mathrm{a}}$ & $6.2 \pm 0.1^{\mathrm{b}}$ \\
\hline & $\mathrm{Pm}$ & $357 \pm 4^{\mathrm{a}}$ & $11.2 \pm 2.2^{\mathrm{bc}}$ & $54 \pm 4^{\mathrm{a}}$ & $0.09 \pm 0.01^{\mathrm{a}}$ & $5.0 \pm 0.2^{b}$ & $0.40 \pm 0.08^{\mathrm{a}}$ & $5.6 \pm 0.6^{\mathrm{a}}$ \\
\hline \multirow[t]{2}{*}{ Park } & $\mathrm{Pl}$ & $572 \pm 6^{\mathrm{a}}$ & $6.9 \pm 0.4^{\mathrm{ab}}$ & $72 \pm 4^{\mathrm{a}}$ & $0.17 \pm 0.02^{\mathrm{b}}$ & $5.2 \pm 0.1^{b c}$ & $0.22 \pm 0.04^{\mathrm{a}}$ & $7.4 \pm 0.5^{\mathrm{b}}$ \\
\hline & $\mathrm{Pm}$ & $434 \pm 5^{\mathrm{a}}$ & $8.3 \pm 1.4^{\mathrm{b}}$ & $69 \pm 3^{a}$ & $0.16 \pm 0.01^{\mathrm{b}}$ & $5.6 \pm 0.1^{\mathrm{c}}$ & $0.51 \pm 0.07^{\mathrm{a}}$ & $7.2 \pm 0.4^{b}$ \\
\hline \multirow[t]{2}{*}{ Metallurgical plant } & Pl & $581 \pm 6^{\mathrm{a}}$ & $8.8 \pm 0.2^{\mathrm{b}}$ & $68 \pm 3^{\mathrm{a}}$ & $0.09 \pm 0.01^{\mathrm{a}}$ & $5.3 \pm 0.1^{\mathrm{c}}$ & $0.42 \pm 0.04^{\mathrm{a}}$ & $7.0 \pm 0.3^{b}$ \\
\hline & $\mathrm{Pm}$ & $1254 \pm 63^{\mathrm{b}}$ & $3.8 \pm 0.6^{\mathrm{a}}$ & $70 \pm 2^{\mathrm{a}}$ & $0.18 \pm 0.01^{\mathrm{bc}}$ & $5.0 \pm 0.1^{\mathrm{bc}}$ & $0.46 \pm 0.08^{\mathrm{a}}$ & $7.2 \pm 0.2^{\mathrm{b}}$ \\
\hline
\end{tabular}

Data are expressed as the mean \pm SD. The different letters denote significant differences between the contents of AA, Chl, RWC, pH, GPX, and proline $(p<0.05)$

at the road and was positively correlated with the Fe and Mn content in the washed samples and with $\mathrm{Pb}, \mathrm{Zn}, \mathrm{Fe}$ and $\mathrm{Mg}$ in the unwashed samples. A similar dependence was also found in studies that were conducted by Kandziora-Ciupa et al. (2013, 2017). Many authors have reported increased GPX activity in response to elevated potentially toxic metal concentrations (Verma and Dubey 2003; Kafel et al. 2010; Doğanlar and Atmaca 2011; Nadgórska-Socha et al. 2013; Marchand et al. 2016).

Relative water content (RWC) is the level of water that is required in plants to maintain a physiological balance (Rai and Panda 2014). According to Krishnaveni (2013), RWC is one of ecophysiological indicators of environmental stress in plants. In our study, the average relative water content in the leaves of Plantago major was nearly $64 \%$ and was nearly $67 \%$ for Plantago lanceolata, which confirms that the selected plants are resistant to water stress. The lowest values for both species were observed at the road (Table 3).

The leaf $\mathrm{pH}$, which is a common physiological parameter, is also suggested to be an indicator of plant stress (Krishnaveni et al. 2013; Husson et al. 2018). The pH of the extracts from the leaves in the study area ranged from 4.5 to 5.6. The lowest $\mathrm{pH}$ was recorded in both study species at the road. The average $\mathrm{pH}$ for the Plantago major leaves was 5.21, and it was 4.98 for Plantago lanceolata (Table 3 ). The values of the leaf $\mathrm{pH}$ that were obtained were lower for both species than the results of a field study in Sosnowiec (Poland) (Skrynetska et al. 2018). Krishnaveni et al. (2013) also recorded a decrease in the leaf $\mathrm{pH}$ values at polluted sites. By contrast, a laboratory study conducted by Cornelissen et al. (2011) reported that leaf $\mathrm{pH}$ is largely a species-specific trait, and therefore, the investigated species could maintain a leaf $\mathrm{pH}$ independently from the soil environment. Studies conducted by Sharma et al. (2013), Zhang et al. (2016) and Bharti et al. (2018) emphasised that a lower leaf $\mathrm{pH}$ is connected with the presence of $\mathrm{SO}_{\mathrm{x}}$ and $\mathrm{NO}_{\mathrm{x}}$ in the air. This fact suggested us to conclude that the leaf $\mathrm{pH}$ depends directly on air quality.

Studies on chlorophyll content are considered to be relevant as its level is connected with tolerance in contaminated environments (Pathak et al. 2011; Rai and Panda 2014;
Ogunkunle et al. 2015; Nadgórska-Socha et al. 2017). We observed comparable results for Plantago major and Plantago lanceolata. The average contents in the leaves of Plantago major and Plantago lanceolata were $0.14 \mathrm{mg} \mathrm{g}^{-1}$ f.w. and $0.13 \mathrm{mg} \mathrm{g}^{-1}$ f.w., respectively (Table 3). Previous field studies have recorded a higher total chlorophyll content in the leaves of Plantago major and Plantago lanceolata in Sosnowiec, Poland (Skrynetska et al. 2018) and in the leaves of Plantago lanceolata in Dąbrowa Górnicza, Poland (Nadgórska-Socha et al. 2017). The content of Chl can be affected by high temperature, drought, salt stress, light intensity, gaseous pollutants and potentially toxic metal contamination (Pandey et al. 2015; Zhang et al. 2016).

Another important indicator of physiological condition of a plant is the content of ascorbic acid (AA), which is a strong reducing agent that activates many defence mechanisms in plants, whereby increased ascorbic acid content enhances pollution tolerance (Pandey et al. 2015; Zhang et al. 2016; Nadgórska-Socha et al. 2017). Ascorbic acid is located mainly in the chloroplast and plays an important role in the synthesis of the cell walls, cell division and the processes that are associated with detoxification (Ogunkunle et al. 2015). In our study, the average AA content in the leaves of Plantago major was $0.46 \mathrm{mg} \mathrm{g}^{-1}$ f.w., while for Plantago lanceolata, it was $0.37 \mathrm{mg} \mathrm{g}^{-1}$ f.w. The lowest AA content was observed in the leaves of Plantago lanceolate at the park (Table 3). A much lower AA content was found in the leaves of Plantago major in a field study in Sosnowiec, Poland (Skrynetska et al. 2018). As was reported by Tripathi and Gautam (2007), an increase in the AA content in all plant species may be due to the increased rate of the production of reactive oxygen species. In a field study conducted by Nadgórska-Socha et al. (2016), a decreasing tendency was found in the leaves of R. pseudoacacia, and an increase in the AA content was found in the leaves of M. album at contaminated sites. Some studies have also reported a high concentration of AA at industrial sites (Agbaire and Esiefarienrhe 2009; Meerabai et al. 2012; Ogunkunle et al. 2015).

Calculating the air pollution tolerance index (APTI) enables the tolerance of plants to air pollution to be determined 
and the biochemical parameters that are responsible for resistance to environmental stress factors to be found. In our study, Plantago major and Plantago lanceolata had a narrow range of tolerance in the APTI index (5.6 to 7.4). It was found that the relative APTI average of Plantago major was 6.7 while it was 6.8 for Plantago lanceolata, thus indicating that both are sensitive to air pollution. The road site had the lowest APTI values for both of the study species (Table 3). According to the classification of Singh and Rao (1983), the investigated plants are species that are sensitive to air pollution. Low values of APTI were also noted in both contaminated and conventionally clean sites in Sosnowiec, Poland (Skrynetska et al. 2018). In Dąbrowa Górnicza, Poland, the APTI of Plantago lanceolata was higher (8.43-14.57), especially at noncontaminated sites compared with contaminated sites (Nadgórska-Socha et al. 2017). Another study in Southern Poland (Miasteczko Śląskie, Katowice, Jaworzno) using Robinia pseudoacacia and Melandrium album at potentially toxic metal-contaminated sites recorded a mean APTI value for all of the investigated sites at 9.4 for R. pseudoacacia and 8.7 for M. album (Nadgórska-Socha et al. 2016). Zhang et al. (2016) identified species that are tolerant to air pollution (Magnolia denudata, Diospyros kaki, Ailanthus altissima, Fraxinus chinensis and Rosa chinensis), which had been collected from two heavy traffic roadside sites and one suburban site in Beijing and recommended it to be planted at locations where there is heavy traffic. Bharti et al. 2018 estimated the APTI of 25 plant species that were growing at the Talkatora Industrial Area, India, and determined that Polythalia longifolia was the species that was most sensitive to air pollution.

A plant species with a higher APTI can be used in green belts and should be given priority for replantation in urban and industrial areas in order to reduce the effects of air pollution (Sisodia and Dutta 2016; Achakzai et al. 2017; Bharti et al. 2018). A plant species with a lower APTI can be recommended as a bioindicator and for environmental monitoring (Nadgórska-Socha et al. 2016, 2017; Bharti et al. 2018). The results that were obtained indicate that Plantago major and Plantago lanceolata species can be classified as being sensitive to air pollution and can be recommended for bioindicative research in urban and industrial areas.

A clear correlation was found between the $\mathrm{pH}$ value and the content of $\mathrm{Mn}$ and $\mathrm{Zn}\left(r^{2}=0.5\right.$ and $r^{2}=0.87$, respectively $)$ and between the $\mathrm{Chl}$ and $\mathrm{Pb}$ content $\left(r^{2}=-0.85\right)$ in the washed plant material. Much stronger correlations were observed in the unwashed material. A correlation was found between the dehydrogenase activity and the content of $\mathrm{Pb}$, $\mathrm{Fe}, \mathrm{Mn}$ and $\mathrm{Zn}\left(r^{2}=0.76 ; r^{2}=0.92 ; r^{2}=0.96\right.$ and $r^{2}=0.57$, respectively). Significant positive correlations were found between the RWC and $\mathrm{Cd}$ and $\mathrm{Zn}$ concentrations $\left(r^{2}=0.81 ; r^{2}=\right.$ 0.7 , respectively), between the total chlorophyll and $\mathrm{Cd}$ content $\left(r^{2}=0.66\right)$ and between the $\mathrm{pH}$ value and the content of
Zn $\left(r^{2}=0.72\right)$. Negative correlations were observed between proline content and the content of $\mathrm{Pb}, \mathrm{Fe}, \mathrm{Zn}$ and $\mathrm{Cd}$ in the unwashed samples $\left(r^{2}=-0.61 ; r^{2}=-0.76 ; r^{2}=-0.58\right.$ and $r^{2}=-0.56$, respectively).

Although the Plantago major and Plantago lanceolata species that were investigated demonstrated different ecophysiological responses to environmental pollution, they can be recommended as unified bioindicators because of their wide dispersion in Europe, North America, and other regions of the world, e.g. South Africa (Kardel et al. 2010). The ability of this plant to accumulate metals can be also used in phytostabilisation and environmental risk assessment studies (Gucwa-Przepióra et al. 2016; Romeh et al. 2016). Moreover, it is important to continue this kind of research in order to determine plants with a tolerance or resistance to environmental pollution that can be used in developing green belts or to provide a low-cost and eco-friendly approach for reducing air pollution.

\section{Conclusions}

The examinations of the leaves of Plantago major and Plantago lanceolata showed anatomical, biochemical and ecophysiological changes in the plant samples that had been collected from an industrialized urban area. Strong correlations were found between the SPL and the ecophysiological parameters (RWC, APTI, Chl, AA, proline content). The metal content also correlated with the biochemical and ecophysiological indexes to different degrees depending on the specific element.

The difference in metal concentrations between the washed and unwashed plant material is an essential distinction. The statistical analysis demonstrated the necessity of washing the plant material that is used in metal bioaccumulation studies because this factor affects the experimental accuracy.

According to the SEM-EDX results, a higher content of Al, $\mathrm{Fe}, \mathrm{Si}$ and Mn was observed on the adaxial leaf surfaces at the road and metallurgical plant sites. During such an analysis, researchers should take into account the detection limit and depth of the beam penetration because tracking the trace element content in particles $>2 \mu \mathrm{m}$ is quite difficult. Therefore, for bioaccumulation studies, SEM-EDX analysis with an additional analysis of the metal concentration (AAS, ICP etc.) is recommended.

The results demonstrated that Plantago major had a higher tolerance ability to environmental pollution compared with Plantago lanceolata at the site of the metallurgical plant - an area with an extremely high metal content, which ensured its greater adaptation ability to stress factors. The calculation of the APTI index demonstrated that the plant species that were studied have a narrow range (5.6-7.4) and are sensitive to air pollutants, including potentially toxic 
metals, which suggests their usefulness as bioindicators of the environmental state.

Acknowledgements We would like to express our gratitude to the anonymous reviewers for their careful reading of our manuscript and their insightful comments and suggestions.

Funding This work was co-funded by the university statutory activity funds for young researchers.

\section{Compliance with ethical standards}

Conflict of interest The authors declare that they have no conflict of interest.

Open Access This article is distributed under the terms of the Creative Commons Attribution 4.0 International License (http:// creativecommons.org/licenses/by/4.0/), which permits unrestricted use, distribution, and reproduction in any medium, provided you give appropriate credit to the original author(s) and the source, provide a link to the Creative Commons license, and indicate if changes were made.

\section{References}

Abd El-Gawad A, Mashaly IA, Abu Ziada ME, Deweeb MR (2015) Phytotoxicity of three Plantago species on germination and seedling growth of hairy beggarticks (Bidens pilosa L.). Egypt J Basic Appl Sci 2:303-309

Achakzai K, Khalid S, Adrees M, Bibi A, Ali S, Nawaz R, Rizwan M (2017) Air pollution tolerance index of plants around brick kilns in Rawalpindi, Pakistan. J Environ Manag 190:252-258. https://doi. org/10.1016/j.jenvman.2016.12.072

Agbaire P, Esiefarienrhe E (2009) Air pollution tolerance indices (APTI) of some plants around Otorogun gas plant in Delta State, Nigeria. J Appl Sci Environ Manag 13(1):11-14. https://doi.org/10.5897/ AJB2014.13616

Alloway A (1997) Chemical principles of environmental pollution. Springer, Netherlands, pp 41-56

Alves ES, Moura BB, Domingos M (2008) Structural analysis of Tillandsia usneoides L. exposed to air pollutants in Sao Paulo City, Brazil. Water Air Soil Pollut 189:61-68

Amoakwah E, Van Slycken S, Tack FMG, Essumang D (2013) Assessing the extraction efficiency of $\mathrm{CaCl}_{2}$ and Rhizon extraction methods after the application of organic matter and $\mathrm{CaCl}_{2}$ as soil amendments to enhance the mobility of Cd and Zn. J Environ Anal Toxicol 3:167. https://doi.org/10.4172/2161-0525.1000167

Arnon DI (1949) Copper enzymes in isolated chloroplast: polyphenol oxidase in Beta vulgaris. Plant Physiol 24:1-15

Bates L, Waldren R, Teare D (1973) Rapid determination of free proline for water-stress studies. Plant Soil 39:205-207

Bharti SK, Trivedi A, Kumar N (2018) Air pollution tolerance index of plants growing near an industrial. Urban Climate 24:820-829. https://doi.org/10.1016/j.uclim.2017.10.007

Bussotti F, Paolo Grossoni P, Batistoni P, Ferretti M, Cenni E (1995) Preliminary studies on the ability of plant barriers to capture lead and cadmium of vehicular origin. Aerobiologia 11:11-18

Chwil S, Kozłowska-Strawska J, Tkaczyk P, Chwil P, Matraszek R (2015) Assessment of air pollutants in an urban agglomeration in Poland made by the biomonitoring of trees. J Elem 20(4):813-826. https://doi.org/10.5601/jelem.2015.20.1.742
Cornelissen J, Sibma F, Logtestijn R, Broekman R, Thompson K (2011) Leaf $\mathrm{pH}$ as a plant trait: species-driven rather than soil-driven variation. Funct Ecol 25:449-455. https://doi.org/10.2307/41239279

Dao L, Morrison L, Zhang H, Zhang C (2014) Influences of traffic on Pb, $\mathrm{Cu}$ and $\mathrm{Zn}$ concentrations in roadside soils of an urban park in Dublin, Ireland. Environ Geochem Health 36:333-343. https://doi. org/10.1007/s10653-013-9553-8

Djingova R, Kuleff I, Markert B (2004) Chemical fingerprint of plants. Ecol Res 19:3-11. https://doi.org/10.1111/j.1440-1703.2003.00602. $\mathrm{x}$

Doğanlar Z, Atmaca M (2011) Influence of airborne pollution on Cd, Zn, $\mathrm{Pb}, \mathrm{Cu}$ and $\mathrm{Al}$ accumulation and physiological parameters of plant leaves in Antakya (Turkey). Water Air Soil Pollut 214(1/4):509-523

Dziubanek G, Piekut A, Rusin M, Baranowska M, Hajok I (2015) Contamination of food crops grown on soils with elevated heavy metals content. Ecotoxicol Environ Saf 118:183-189. https://doi. org/10.1016/j.ecoenv.2015.04.032

Fang WC, Kao C (2000) Enhanced peroxidase activity in rice leaves in response to excess iron, copper and zinc. Plant Sci 158:71-76

Giacomino A, Malandrino M, Colombo ML, Miaglia S, Maimone P, Blancato S, Conca E, Abollino O (2016) Metal content in dandelion (Taraxacum officinale) leaves: influence of vehicular traffic and safety upon consumption as food. J Chem 2016. https://doi.org/10. 1155/2016/9842987

Gomes de Andrade C, Mendes de Souza Mesquita L, Murador D, Cavalcante Braga A, Vera de Rosso V, Garcia de Almeida OJ, Vilegas W (2018) Application of electrospray ionization mass spectrometry fingerprinting associated with macroscopic and histological analysis for Plantago major herbal infusions quality control. Food Res Int 107:314-324

Gucwa-Przepióra E, Nadgórska-Socha A, Fojcik B, Chmura D (2016) Enzymatic activities and arbuscular mycorrhizal colonization of Plantago lanceolata and Plantago major in a soil root zone under heavy metal stress. Environ Sci Pollut Res 23(5):4742-4475. https:// doi.org/10.1007/s11356-015-5695-9

Husson O, Audebert A, Benada J et al (2018) Leaf Eh and pH: a novel indicator of plant stress. Spatial, temporal and genotypic variability in rice (Oryza sativa L.). Agronomy 8:209. https://doi.org/10.3390/ agronomy 8100209

Kabata-Pendias A, Pendias H (2001) Trace elements in soils and plants third ed. CRC press, Boca Raton FL

Kafel A, Nadgórska-Socha A, Gospodarek J, Babczyńska A, Skowronek M, Kandziora M, Rozpendek K (2010) The effects of Aphis fabae infestation on the antioxidant response and heavy metal content in field grown Philadelphus coronarius plants. Sci Total Environ 408(5):1111-1119

Kandziora-Ciupa M, Nadgórska-Socha A, Ciepał R, Słomnicki A (2013) Soil contamination with zinc, cadmium and lead in the city of Zabrze. Ecol Chem Eng A 20(1):47-54

Kandziora-Ciupa M, Ciepał R, Nadgórska-Socha A, Barczyk G (2016) Accumulation of heavy metals and antioxidant responses in Pinus sylvestris L. needles in polluted and non-polluted sites. Ecotoxicology 25:970-981

Kandziora-Ciupa M, Nadgórska-Socha A, Barczyk G, Ciepał R (2017) Bioaccumulation of heavy metals and ecophysiological responses to heavy metal stress in selected populations of Vaccinium myrtillus L. and Vaccinium vitis-idaea L. Ecotoxicology 26(7):966-980

Kardel F, Wuyts K, Babanezhad M, Vitharana UWA, Wuytack T, Potters G, Samson R (2010) Assessing urban habitat quality based on specific leaf area and stomatal characteristics of Plantago lanceolata L. Environ Pollut 158:788-794

Kedar KA, Chaudhari SR, Rao AS (2018) Dataset on leaf surface and elemental study of four species of Bignoniaceae family by SEMEDAX. Data Brief 17:1188-1195

Keller T, Schwanger H (1977) Air pollution and ascorbic acid. Eur J Forest Pathol 7:338-350 
Krishnaveni M (2013) Air pollution tolerance index and antioxidant activity of Parthenium hysterophorus. J Pharm Res 7:296-298. https:// doi.org/10.1016/j.jopr.2013.03.025

Krishnaveni M, Amsavalli L, Chandrasekar R, Durairaj S, Madhiyan P (2013) Biochemical changes in medicinal plant leaves as a biomarker of pollution. Res J Pharm Technol 6(5):537-543

Kumar N, Pal M, Singh A, Kumar SaiRam R, Srivastava GH (2010) Exogenous proline alleviates oxidative stress vase life in rose (Rosa hybrid L. "Grand Gala"). Sci Hortic 127:79-85

Kurteva M (2009) Comparative study on Plantago major and P. lanceolata (Plantaginaceae) as bioindicators of the pollution in the region of the Asarel Copper Dressing Works. Phytologia Balcanica Sofia 15(2): 261-271

Lakshmi P, Sarvanti L, Srinivas N (2008) Air pollution tolerance index of various plants species growing in industrial areas. Ecoscan 2:203206

Levei L, Kovacs E, Hoaghia M-A, Ozunu A (2018) Accumulation of heavy metals in Plantago major grown in urban and postindustrial areas. Studia Ubb Chemia 1:87-98. https://doi.org/10. 24193/subbchem.2018.1.07

Liang J, Fang HL, Zhang TL, Wang XX, Liu YD (2017) Heavy metal in leaves of twelve plant species from seven different areas in Shanghai, China. Urban For Urban Green 27:390-398. https://doi. org/10.1016/j.ufug.2017.03.006

Lin CC, Chen SJ, Huang KL, Hwang WI, Chang-Chien GP, Lin WY (2005) Characteristics of metals in nano/ultrafine/fine/coarse particles collected beside a heavily trafficked road. Environ Sci Technol 39:8113-8122. https://doi.org/10.1021/es048182a

Lin A, Zhang X, Zhu Y-G, Zhao F-J (2008) Arsenate induced toxicity: effects on antioxidative enzymes and DNA damage in Vicia faba. Environ Toxicol Chem 27:413-419. https://doi.org/10.1897/07266R.1

Maher BA, Ahmed IAM, Davison B, Karloukovski V, Clarke R (2013) Impact of roadside tree lines on indoor concentrations of trafficderived particulate matter. Environ Sci Technol 47:13737-13744. https://doi.org/10.1021/es404363m

Marchand L, Grebenshchykova Z, Mench M (2016) Intra-specific variability of the guaiacol peroxidase (GPOD) activity in roots of Phragmites australis exposed to copper excess. Ecol Eng 90:5762. https://doi.org/10.1016/j.ecoleng.2016.01.055

Mattioli R, Costantino P, Trovato M (2009) Proline accumulation in plants. Plant Signal Behav 4(11):1016-1018

Meerabai G, Venkata Ramana C, Rasheed M (2012) Effect of industrial pollutants on physiology of Cajanus cajan (L.)-Fabaceae. Int J Environ Sci 2(4):1889-1894. https://doi.org/10.6088/ijes. 00202030071

Meers E, Samson R, Tack F, Ruttens A, Vandegehuchte M, Vangronsveld J, Verloo M (2007) Phytoavailability assessment of heavy metals in soils by single extractions and accumulation by Phaseolus vulgaris. Environ Exp Bot 60(3):385-396

Muszyńska E, Hanus-Fajerska E, Ciarkowska K (2018) Studies on lead and cadmium toxicity in Dianthus carthusianorum calamine ecotype cultivated in vitro. Plant Biol 20(3):474-482. https://doi.org/10. 1111/plb.12712

Nadgórska-Socha A, Ptasiński B, Kita A (2013) Heavy metal bioaccumulation and antioxidant responses in Cardaminopsis arenosa and Plantago lanceolata leaves from metalliferous and nonmetalliferous sites. Ecotoxicology 22:1422-1434. https://doi.org/ 10.1007/s10646-013-1129-y

Nadgórska-Socha A, Kandziora-Ciupa M, Ciepal R, Barczyk G (2016) Robinia pseudoacacia and Melandrium album in trace elements biomonitoring and air pollution tolerance index study. Int $\mathrm{J}$ Environ Sci Technol 13:1741-1752. https://doi.org/10.1007/ s13762-016-1010-7

Nadgórska-Socha A, Kandziora-Ciupa M, Trzesicki M, Barczyk G (2017) Air pollution tolerance index and heavy metal bioaccumulation in selected plant species from urban biotopes. Chemosphere 183:471-482. https://doi.org/10.1016/j. chemosphere.2017.05.128

Ogunkunle C, Suleiman L, Oyedeji S, Awotoye O, Fatoba P (2015) Assessing the air pollution tolerance index and anticipated performance index of some tree species for biomonitoring environmental health. Agrofor Syst 89:447-454. https://doi.org/10.1007/s10457014-9781-7

Ostrowska A, Gawliński S, Szczubiałka Z (1991) In: Method of analysis and estimate soil and plants property, Catalogue of the Environmental Protection Institute Warsaw pp 334-336 (in Polish)

Pandey AK, Pandey M, Mishra A, Tiwary SM, Tripathi BD (2015) Air pollution tolerance index and anticipated performance index of some plant species for development of urban forest. Urban For Urban Green 14:866-871

Pathak V, Tripathi B, Mishra V (2011) Evaluation of anticipated performance index of some tree species for green belt development to mitigate traffic generated noise. Urban For Urban Green 10:61-66. https://doi.org/10.1016/j.ufug.2010.06.008

Prajapati S, Tripathi B (2008) Seasonal variation of leaf dust accumulation and pigment content in plant species exposed to urban particulates pollution. J Environ Qual 37:865-870. https://doi.org/10.2134/ jeq2006.0511

Przedpełska E, Wierzbicka M (2007) Arabidopsis arenosa (Brassicaceae) from a lead-zinc waste heap in southern Poland - a plant with high tolerance to heavy metals. Plant Soil 299:43-53. https://doi.org/10. 1007/s11104-007-9359-5

Rai P, Panda L (2014) Dust capturing potential and air pollution tolerance index (APTI) of some road side tree vegetation in Aizawl, Mizoram, India: an Indo-Burma hot spot region. Air Qual Atmos Health 7:93-101. https://doi.org/10.1007/s11869013-0217-8

Regulation by the Minister of Environment dated 9 September 2002. Official Gazette No. 165, Pos. 1359th (in Polish)

Remon E, Bouchardon J-L, Guédard ML, Bessoule J-J, Conord C (2013) Are plants useful as accumulation indicators of metal bioavailability. Environ Pollut 175:1-7. https://doi.org/10.1016/j.envpol.2012.12. 015

Robinson MF, Heath J, Mansfield TA (1998) Disturbances in stomatal behaviour caused by air pollutants. J Exp Bot 49:461-469

Romeh A, Khamis M, Metwally S (2016) Potential of Plantago major L. for phytoremediation of lead-contaminated soil and water. Water Air Soil Pollut 227:9. https://doi.org/10.1007/s11270-015-2687-9

Ross S (1994) Toxic metals in soil-plant systems. John Wiley \& Sons, Chichester; New York

Schreck E, Foucault Y, Sarret G, Sobanska S, Cécillon L, CastrecRouelle M, Uzu G, Dumat C (2012) Metal and metalloid foliar uptake by various plant species exposed to atmospheric industrial fallout: mechanisms involved for lead. Sci Total Environ 427-428:253-262

Serbula S, Milljkovic D, Kovacevic R, Ilic A (2012) Assessment of airborne heavy metal pollution using plant parts and topsoil. Ecotoxicol Environ Saf 76:209-214. https://doi.org/10.1016/j. ecoenv.2011.10.009

Sharma M, Panwar N, Arora P, Luhach J, Chaudhry S (2013) Analysis of biological factors for determination of air pollution tolerance index of selected plants in Yamuna Nagar, India. J Environ Biol 34:509514

Singh SK, Rao DN (1983) Evaluation of the plants for their tolerance to air pollution, Proceedings symposium on air pollution control held at IIT, Delhi. pp 218-224

Sisodia A, Dutta S (2016) Air pollution tolerance index of certain plant species: a study of national highway no-8, India. J Environ Res Dev 10(04):723

Skrynetska I, Ciepał R, Kandziora-Ciupa M, Barczyk G, Nadgórska-Socha A (2018) Ecophysiological responses to 
environmental pollution of selected plant species in an industrial urban area. Int J Environ Res 12:255. https://doi.org/10. 1007/s41742-018-0088-9

Słomka A, Libik-Konieczny M, Kuta E, Miszalski Z (2008) Metalliferous and non-metalliferous populations of Viola tricolor represent similar mode of antioxidative response. J Plant Physiol 165:1610-1619. https://doi.org/10.1016/j.jplph. 2007.11.004

Stafford AD, Anderson CW, Hedley MJ, McDowell RW (2016) Cadmium accumulation by forage species used in New Zealand livestock grazing systems. Geoderma Regional 7:11-18. https:// doi.org/10.1016/j.geodrs.2015.11.003

Tantrey MS, Agnihotri RK (2010) Chlorophyll and proline content of gram (Cicer arietinum L.) under cadmium and mercury treatment. Res J Agric Sci 1(2):119-122

The local revitalization program of the city of Ruda Ślaska until 2030 (2015) Resolution no. PRP 2008-07.8 of the Ruda Ślaska City Council of January 22, 2015. (in Polish)

Tinkov A, Nemereshina O, Suliburska J, Gatiatulina E, Regula J, Nikonorov A, Skalny A (2016) Comparative analysis of the trace element content of the leaves and roots of three Plantago species. Biol Trace Elem Res 173:225-230

Tripathi A, Gautam M (2007) Biochemical parameters of plants as indicators of air pollution. J Environ Biol 28:127-132

Uka N, Hogarh J, Belford D (2017) Morpho-anatomical and biochemical responses of plants to air pollution. Int J Mod Bot 7(1):1-11. https:// doi.org/10.5923/j.ijmb.20170701.01

Verbruggen N, Hermans C (2008) Proline accumulation in plants: a review. Amino Acids 35
Verma S, Dubey RS (2003) Lead toxicity induces lipid peroxidation and alters the activities of antioxidant enzymes in growing rice plants. Science 164:645-655

Wagoner S (1975) Leaf cuticular and morphological variations in Plantago lanceolata as indicators of environmental pollution. Tennessee Acad Sci 50:79-83

Weerakkody U, Dover JW, Mitchell P, Reiling K (2018) Quantification of the traffic-generated particulate matter capture by plant species in a living wall and evaluation of the important leaf characteristics. Sci Total Environ 635:1012-1024

Wójcik M, Sugier P, Siebielec G (2014) Metal accumulation strategies in plants spontaneously inhabiting $\mathrm{Zn}-\mathrm{Pb}$ waste deposits. Sci Total Environ 487:313-322

Zhang P, Liu Y, Chen X, Yang Z, Zhu M, Li Y (2016) Pollution resistance assessment of existing landscape plants on Beijing streets based on air pollution tolerance index method. Ecotoxicol Environ Saf 132: 212-223. https://doi.org/10.1016/j.ecoenv.2016.06.003

Zheljazkov VD, Nielsen NE (1996) Effect of heavy metals on peppermint and corn-mint. Plant Soil 178:59-66

Zheljazkov VD, Jeliazkova EA, Kovacheva N, Dzhurmanski A (2008) Metal uptake by medicinal plant species grown in soils contaminated by a smelter. Environ Exp Bot 64(3):207-216. https://doi.org/10. 1016/j.envexpbot.2008.07.003

Publisher's note Springer Nature remains neutral with regard to jurisdictional claims in published maps and institutional affiliations. 